LIFE'S DEVICES 



\section{STEVEN VOGEL}

\section{Life's Devices}

\section{THE PHYSICAL WORLD OF}

\section{ANIMALS AND PLANTS}

ILLUSTRATED BY

ROSEMARY ANNE CALVERT

PRINCETON UNIVERSITY PRESS

PRINCETON, N.J. 
Copyright $\odot 1988$ by Princeton University Press

Published by Princeton University Press, 41 William Street,

Princeton, New Jersey 08540

In the United Kingdom: Princeton University Press,

Chichester, West Sussex

\section{All Rights Reserved}

Library of Congress Cataloging-in-Publication Data

Vogel, Steven, 1940-

Life's devices: the physical world of animals and plants /

Steven Vogel; illustrated by Rosemary Anne Calvert.

p. $\mathrm{cm}$.

Bibliography: $p$.

Includes index.

ISBN 0-691-08504-8 (alk. paper) ISBN 0-691-02418-9 (pbk.)

1. Biophysics. 2. Biomechanics. I. Title.

QH505.V634 1988

574.19'1-dc19 88-17603

This book has been composed in Linotron Baskerville

Princeton University Press books are printed on acid-free paper, and meet the guidelines for permanence and durability of the Committee on Production Guidelines for Book Longevity of the Council on Library Resources

Printed in the United States of America

$\begin{array}{lll}9 & 8 & 7\end{array}$ 
To my father, Max Vogel,

with great affection and gratitude,

on the occasion of

his seventy-fifth birthday 
